\title{
Flashes and curtains
}

Another morning comes, to move forward through the unknown.

The joy of seeking a blank plot rich in colors, shapes and lights.

Awake, I suppose.

Life...through my thick glasses, busy, fast, steady, seemingly usual.

But down the hallway was an open door:

A sunny day and humid breeze, ready to enjoy a brisk pause, and a classy cup of coffee on the sidewalk.

My hand grabbed the cup's handle then froze...

For the saucer grasped my attention:

Ancient sophistication

thrown into folds of

carefully-sculpted geometric shapes...

I saw a theater of history

surrounding the saucer's white center.

Three black dots had appeared on its stage, moments before thousands of

black meteoroids went astray,

burnt into flashes of light.

And the theater's curtains soon to follow,

closing vision and lasting memories.

\section{Osama M Mustafa}

Correspondence to Osama M Mustafa, College of Medicine, Alfaisal University, Riyadh 11533, Kingdom of Saudi Arabia; omustafa@alfaisal.edu

Competing interests None declared.

Provenance and peer review Not commissioned; internally peer reviewed.

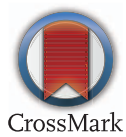

To cite Mustafa OM. Med Humanit 2017;43:e20.

Published Online First 7 February 2017

Med Humanit 2017;43:e20. doi:10.1136/medhum-2017-011184 